九州大学学術情報リポジトリ

Kyushu University Institutional Repository

\title{
Face Bypass Damper Application to Overcome Air Conditioning Oversizing Issue
}

Abdul Qayyum Abdul Halim

Fakulti Kejuruteraan Mekanikal, Universiti Teknikal Malaysia Melaka

Boon Tuan Tee

Fakulti Kejuruteraan Mekanikal, Universiti Teknikal Malaysia Melaka

Wan Shah Waliallah Wan Mat Zain

Jabatan Kerja Raya Malaysia

https://doi.org/10.5109/4491961

出版情報：Evergreen. 8 (3)，pp.686-692，2021-09. 九州大学グリーンテクノロジー研究教育センター バージョン：

権利関係 : 


\title{
Face Bypass Damper Application to Overcome Air Conditioning Oversizing Issue
}

\author{
Abdul Qayyum Abdul Halim,**, Boon Tuan Tee ${ }^{1}$, Wan Shah Waliallah Wan \\ Mat Zain ${ }^{2}$ \\ ${ }^{1}$ Fakulti Kejuruteraan Mekanikal, Universiti Teknikal Malaysia Melaka, \\ Hang Tuah Jaya, 76100 Durian Tunggal, Melaka, Malaysia \\ 2 Jabatan Kerja Raya Malaysia, Jalan Sultan Salahuddin, 50480, Wilayah Persekutuan Kuala Lumpur, \\ Malaysia
}

*Author to whom correspondence should be addressed:

E-mail: aqayyum13@gmail.com

(Received January 7, 2021; Revised September 6, 2021; accepted September 6, 2021).

\begin{abstract}
The purpose of this work is to study the impact of a face bypass damper in tackling mould problem caused by an oversized air conditioning system. Comparison was made between the performance of an actual operating AHU and the performance of the AHU after the installation of face bypass damper. Comparison is also made to various simulated model using building energy simulation software to study its effectiveness in solving actual problem. Both actual and simulated result of the face bypass damper shows that it is effective in reducing relative humidity. However, it should not be preferred over a complete replacement with a correctly size AHU due to the energy penalty it incurs.
\end{abstract}

Keywords: Oversizing; Air Conditioning, Computational, Face Bypass Damper

\section{Introduction}

Over the last 10 years, electricity consumption in Malaysia has kept increasing by $11 \%$ on average each year. In 2018, Energy Securities Commission of Malaysia recorded that residential and commercial properties both consumes $49.5 \%$ of total electricity generated $^{1)}$. In addition, the construction industry recorded average increment of $7.2 \%$ annually to cater for rapid population increase and developmental growth of the country ${ }^{2)}$. It is safe to assume that energy consumption will steadily increase in the future.

In urban areas where land is limited, humans have adapted to live in more confined space. Consequently, air conditioning system has widely replaced natural ventilation as the preferred mean to provide comfort. A study by Tang et al reveals that air conditioning system consumed $49 \%$ of electricity in a building ${ }^{3)}$. Unfortunately, its wide use of refrigerant raises concern on its adverse effect on the environment due its high Global Warming Potential. Although the Montreal Protocol has successfully promoted ozone friendly refrigerants, Kibria et al observed that it still contributes to indirect warming impact due to increasing usage especially in densely populated cities $^{4}$. At higher ambient temperature, air conditioning system produced higher Total Equivalent Warming Impact (TEWI) due to higher electrical consumption to meet its requirement ${ }^{5}$. There is also direct impact observed on the environment caused by leakage which releases refrigerant and other pollutants from the system into the environment. Study by $\mathrm{Pal}$ et al is especially worrying since it shows high leakage rate of $8 \%$ and $8.5 \%$ among consumption-intensive consumers in the industrial and residential sector ${ }^{6)}$. With the impact of global warming on earth's temperature, it is estimated that energy demand for air conditioning could increase by around $50 \%^{7)}$. This shows that it is an important area of analysis in order to avoid further stress on the country's energy infrastructure. Shahriari et al. proposed tackling this issue from behavioral point of view by inculcating green human resource trainings in daily activities to reduce human caused environmental degradation ${ }^{8)}$. When implemented correctly, it could expand from individual to the more encompassing societal level. A study by Sato has revealed three driving forces that lead to sustainable societies are organized management, symbol of a clean environment and legacy of the past ${ }^{9}$. While ideal in theory, green human resource has still not fully developed into a cross-cultural model due to the lack of research in developing countries ${ }^{10)}$.

Another method is by improvement on the technological aspects. Many countries have started to address this issue by adopting higher energy efficiency standards for all new air conditioners. Studies conducted 
by Mahlia et al. in Malaysia has shown that installed air conditioner with higher Energy Efficiency Ratio (EER) contributed to more electricity saving ${ }^{11)}$ and lower emission of harmful gases such as $\mathrm{CO}_{2}, \mathrm{CO}$ and $\mathrm{SO}_{2}{ }^{12}$. Unfortunately, this increase in efficiency does not necessarily guarantee lower energy consumption if it is not accompanied with proper capacity sizing.

Despite the availability of references and literatures, earlier studies have shown that oversizing an air conditioning system is prevalent in the industry. A survey by Felts and Bailey conducted in California finds that only $40 \%$ were correctly sized. $20 \%$ of air conditioning installation were oversized by $25 \%$ or less, $40 \%$ oversized by more than $25 \%$ with $10 \%$ of them being more than $50 \%$ oversized $^{13)}$. Another survey conducted among engineers in Hong Kong reveals that $67 \%$ of respondent intentionally oversized the calculation by $10-15 \%{ }^{14)}$. Bacon attributed this phenomenon due to the need of engineers to eliminate uncertainties which leads to calculation based on worst case scenarios especially to unspecified parameters such as occupancy level, infiltration and lighting intensity ${ }^{15}$. Proctor et al even reported of some industry player practice of ignoring sound engineering judgement to suit commercial purpose $^{16)}$. This includes method such as buying distributor overstock, install rejected unit from previous job and installing unsold unit that is sitting in truck or shop. Viera also reported that contractors regularly oversized to reduce time spend to calculate, to lower potential callbacks and to allow extraordinarily low thermostat point in order to reduce after sales complains ${ }^{17)}$. Watanabe demonstrated that the gap between proven best practices with actual contradictory implementation can be attributed to human cognitive ignorance ${ }^{18)}$ which inevitably invites various unintended consequences. A study by McLain et al., for example, shows that an average air conditioner which is oversized by $50 \%$ consumes $10 \%$ more energy ${ }^{19)}$. Another study by Henderson supported McLain's findings and added that more energy is wasted when the degree of oversizing is higher ${ }^{20)}$. James et al. collected data for 368 homes and found increases of energy between $3.7 \%$ to $9.3 \%$ with oversized capacities of between $20 \%$ to $50 \%{ }^{21)}$. Simulation study by Djunaedy et al find that a properly sized oversized Roof Top Unit (RTU) could yield energy saving between $37 \%$ to $48 \%{ }^{22}$.

Additionally, oversizing inhibits air conditioning system's capability to effectively dehumidify supplied air. Shirey et al has shown that the system's cooling coil is incapable of removing any moisture when operated at less than $50 \%$ of its design capacity ${ }^{23)}$. Humidity problem is compounded by the tendency of oversized air conditioning system to cycle on and off at short time interval due to its ability to quickly reduce space temperature ${ }^{24)}$. The continuous cycle of air conditioner is not only ineffective in dehumidifying incoming air, it also could potentially add more moisture because condensate water on cooling coil could evaporates back into the air stream while compressor shuts off. Another study by Khattar et al finds that unlike sensible cooling process, moisture removal process in air conditioner's cooling coil takes a long time to reach steady state ${ }^{25)}$. Thus, a rapidly cycling system would have limited capability to effectively dehumidify incoming air. This phenomenon is indistinguishable regardless of whether the air conditioning system is using direct expansion or chilled water coil. This clearly shows the drawback of an oversized system since it is typically spending more time in partial load condition compared to a properly sized system. Air that is insufficiently dehumidified will raise the relative humidity inside a room and create a conducive environment for mould growth. This unwanted repercussion is highly undesirable since mould is hazardous to human health.

A study by Ito shows that mould growth is highly dependent on temperature and specifically on humidity where parametric growth was observed whenever humidity increases ${ }^{26)}$. In addition, the Public Work Department of Malaysia has released a study identifying constant relative humidity in excess of $70 \%$ as one of the primary determinants of mould growth ${ }^{27}$. When it comes into contact with foam insulation, fungal degradation will cause it to release urea formaldehyde, which has an unpleasant smell and gives rise to other problematic symptoms such as headache, nasal irritation, dizziness, fatigue and nausea ${ }^{28)}$. Other health hazard were reported by Khan and Karuppavil including common cold, hypersensitivity syndrome, respiratory infection, immunity related diseases and neuro-psychiatric problems ${ }^{29}$. Mould is also undesirable because it could cause damage to buildings. The United State Environmental Protection Agency reported that mold decays wood and attract insect pest such as termites and carpenter ants, causes chemical reaction with building materials that causes it to fail ${ }^{30)}$. The accumulated damage caused by mould can be substantial in monetary value. Dybdahl reported that in 2003 alone, more than $\$ 2$ billion mould claims were filed against property insurance policy ${ }^{31)}$. Thus, any sighting of mould in a building should raise concerns and be acted upon, especially in vulnerable places such as hospitals.

To prevent mould growth in a building, the United States Environmental Protection Agency suggested that the main thing to take into account is to prevent any liquid from entering the building specifically from rain, leaked plumbing system or wet building materials ${ }^{30}$. Architectural components play an important role in achieving this since it is capable of both preventing as well as holding moisture. In addition, most building material contains nutrient for mold spores to thrive. A more proactive solution is to add additional equipment into the air conditioning system in order to reduce relative humidity to a level that negates mould propagation. In the context of health industry, this is typically addressed by introducing heating element or by installing desiccant 
dehumidifier to actively dry incoming air before it is supplied into the conditioned area. However, both of these methods incur capital cost and imposed energy penalties in order to be implemented.

Face bypass damper is considered to be used in this study due to its negligible energy input. It is known in the industry as a contributing element to the green building index due to its energy efficiency properties ${ }^{32)}$. It typically modulates to force AHU's return air to bypass the cooling coil. The reduced volume of air passing the coil inevitably reduces energy consumption. The idea to be tested in this study is whether the bypassed air can act as a heater and helps to dehumidify the air and simultaneously solve mould growth problem.

\section{Background and Methodology}

An existing specialist hospital building in Selangor was severely infected by mould, which raised serious health concerns among its occupants. The affected department was air-conditioned at a set temperature of $24^{\circ} \mathrm{C}$ and turned off outside working hours. The air conditioner used a dedicated centralized Air Handling Unit (AHU), with the incoming and outgoing chilled water temperature set at $6.7^{\circ} \mathrm{C}$ and $12.2^{\circ} \mathrm{C}$. The AHU delivers constant air volume through a mixture of outdoor air and re-circulated returning air. Once the cooled air reaches the conditioned space, it absorbs both sensible heat and moisture to its designated condition. A thermostat senses the zone's dry bulb temperature which send signal to modulates the capacity of the cooling coil's sensible load accordingly.

The initial room data recorded by data logger shows a favourable conditions for mould growth, with the average temperature and relative humidity recorded at $21.7^{\circ} \mathrm{C}$ and $70.5 \%$, respectively. Its consistently high relative humidity exceeds maximum value of $70 \%$ recommended in MS1525: Code of Practice on Energy Efficiency and Use of Renewable Energy for Non-Residential Buildings.

Table 1: Parameters of Installed AHU

\begin{tabular}{cc}
\hline AHU Parameters & Value \\
\hline Total Load $(\mathrm{kW})$ & 87.4 \\
Airflow $(\mathrm{L} / \mathrm{s})$ & $4,870.5$ \\
Water Flow Rate $(\mathrm{L} / \mathrm{s})$ & 3.8 \\
Air-Conditioned Area $\left(\mathrm{m}^{2}\right)$ & 4,121 \\
\hline
\end{tabular}

The original AHU actual cooling load demand was then measured and compared to its design capacity to obtain its actual performance. This is done by recording dry bulb and wet bulb temperature of the air entering and leaving the AHU's cooling coil. The entering and leaving temperature data were then used to calculate enthalpy of air and actual total load by using the following equation:

$$
h=c_{p a} \cdot t+x \cdot\left[c_{p w} \cdot t+h_{w e}\right]
$$

Ideally, any oversized air condition system's components should be replaced totally with one that is optimally designed for its utility. Unfortunately, it is not applicable to be applied in this study due to time and fund limitation. To minimize these problems, a face bypass damper was instead proposed to be installed to the original AHU. This additional component allows a portion of the returning air to bypass cooling coil. Chilled water flow entering cooling coil is fixed in order to ensure constant dehumidification ability. A thermostat control regulates the bypass damper and determines appropriate amount of air to flow around the cooling coil. Similar to the original AHU, entering and leaving air data of the AHU with face bypass damper installed were recorded and used to calculate actual total load.

The effectiveness of installing face bypass damper was first observed using building simulation software. The fundamental difference of using building simulation software over other conventional method is its ability to process substantially more information and perform complex analysis that gives more assurance in its result's quality and accuracy. With such advantage, it can simulate different air conditioning system set up and configuration to be evaluated without spending substantial money for experimentation. To highlight the impact of face bypass damper, the software was used to simulate an air conditioning system with added electrical heater system that is traditionally used to overcome hospital's high humidity situation. This method lowers the leaving dry bulb temperature in order to achieve the required relative humidity. The leaving air will later pass through an additional heating coil to reach desired room dry bulb temperature. Additionally, simulation was also done to obtain the performance of an optimally sized AHU.

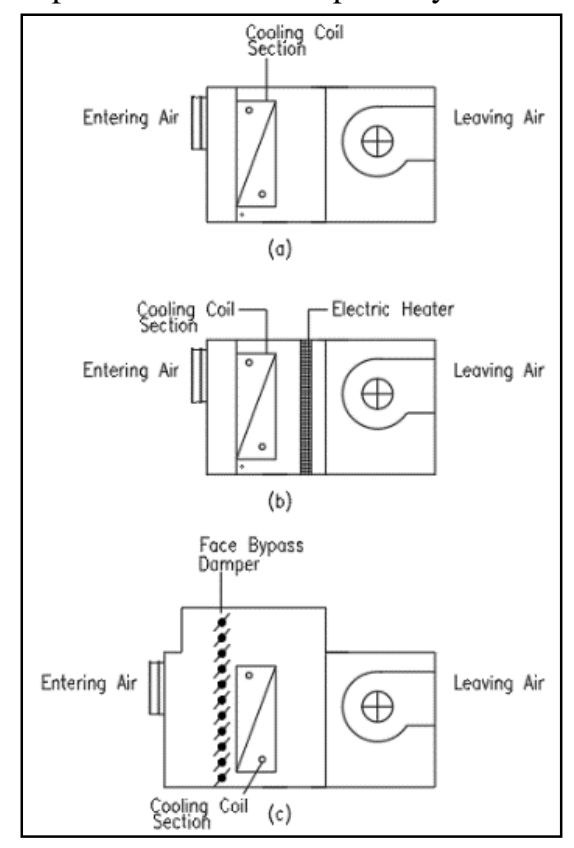


Fig. 1: (a) Installed AHU; (b) AHU with Heater; (c) AHU with Face Bypass Damper

Integrated Environmental Solutions IES-VE 2017 were used as the platform to perform building simulation analysis. This software is able to process huge amount of informations and analyze them holistically in order to produce an approximate solution to a realistic model of reality. It starts with the creation of building model according to actual site condition. Then crucial parameters that influence heat load will then be inserted such as the building fabric properties and internal and external thermal sources. The air conditioning system components, configuration and control system with and without face bypass damper were then created. Thermal calculation was then performed using numerical method to produce the result for analysis.

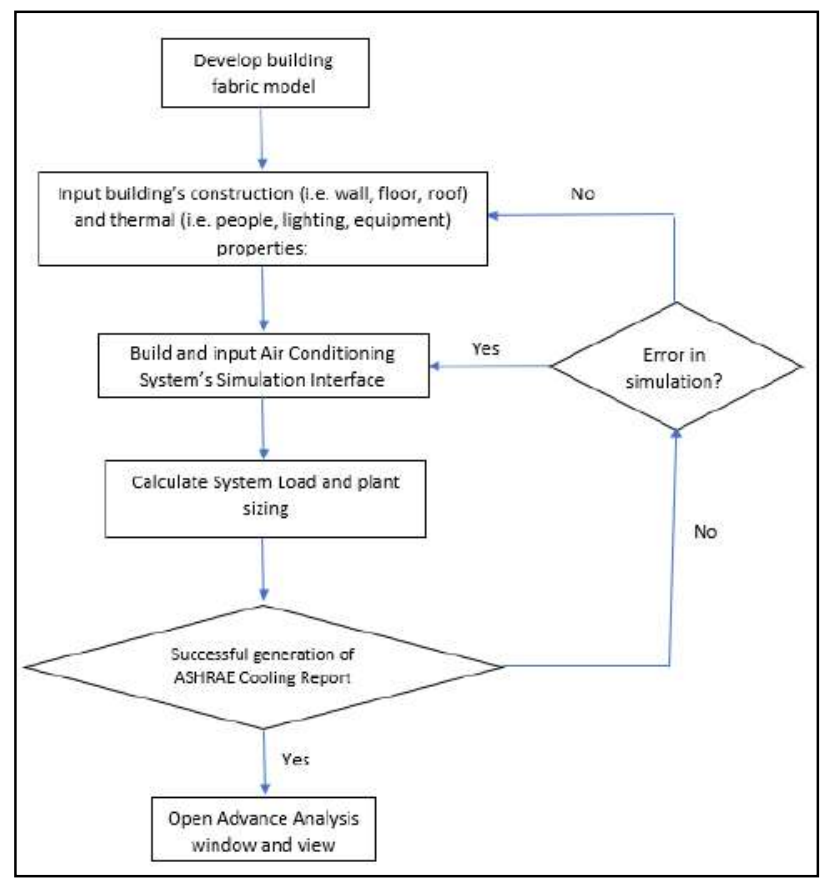

Fig. 2: IES-VE 2017 Simulation Process

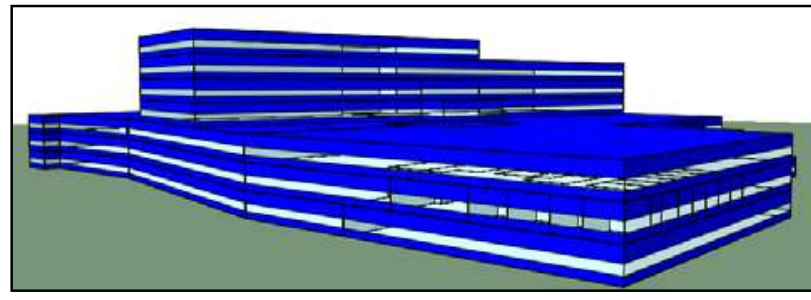

Fig. 3: IES-VE 2017 Building Model

Table 2: Simulation Parameters

\begin{tabular}{|l|l|c|}
\hline \multicolumn{1}{|c|}{ Components } & \multicolumn{2}{c|}{ AHU Area Parameters } \\
\hline \multirow{3}{*}{ External Heat } & Area & $4,121 \mathrm{~m}^{2}$ \\
\cline { 2 - 3 } & Wall & $2.44 \mathrm{~W} / \mathrm{m}^{2} \cdot{ }^{\circ} \mathrm{C}$ \\
\cline { 2 - 3 } & Window & $5.62 \mathrm{~W} / \mathrm{m}^{2} \cdot{ }^{\circ} \mathrm{C}$ \\
\cline { 2 - 3 } & Floor & $3.63 \mathrm{~W} / \mathrm{m}^{2} \cdot{ }^{\circ} \mathrm{C}$ \\
\hline Internal Heat & People & $150 \mathrm{~W}$ \\
\hline
\end{tabular}

\begin{tabular}{|l|l|c|}
\hline \multirow{4}{*}{ System Component } & Lighting & $21.52 \mathrm{~W} / \mathrm{m}^{2}$ \\
\cline { 2 - 3 } & Equipment & $5.38 \mathrm{~W} / \mathrm{m}^{2}$ \\
& a. $\quad$ Fan \\
& b. Cooling Coil \\
& c. Ducting \\
& d. $\quad$ Chilled Water From Chiller \\
\hline
\end{tabular}

\section{Results and Discussion}

From the gathered data shown in Figure 3, the average temperature and relative humidity of the affected area during operational hour were $22.1^{\circ} \mathrm{C}$ and $70.5 \%$, respectively, which were within the favourable range for mould growth. Mold is visibly identified due to its significant formation and accumulation at wall, ceiling and furniture.

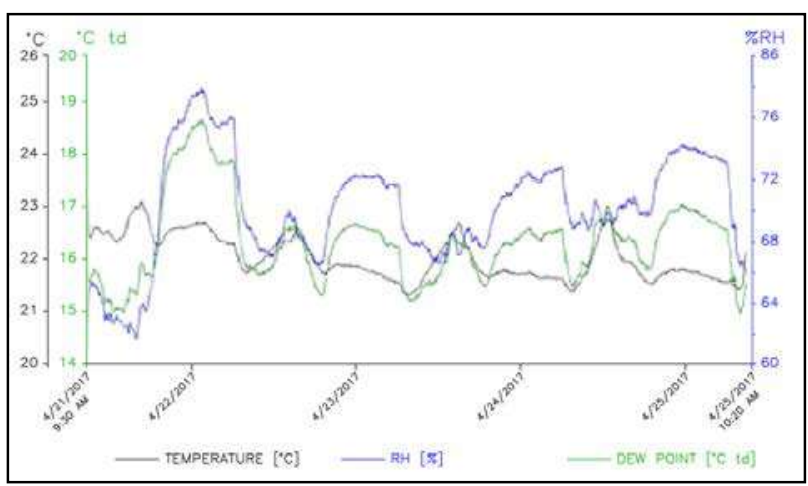

Fig. 4: Installed AHU Temperature and Relative Humidity Profile

While the original AHU shows good result in reducing the dry bulb temperature, it is lacking in its ability to effectively dehumidify incoming air. The relative humidity profile also shows worrying oscillating movement which indicates that the cooling coil is improperly sized and thus requires the modulating valve that control chilled water flow to make continuous adjustment. As the modulating valve throttles to match the necessary requirement, less chilled water enters the cooling coil which inevitably increases its surface dew point temperature. Although this action retains low dry bulb temperature, it significantly reduces the cooling coil's condensation ability to dehumidify incoming air and subsequently raises overall conditioned space relative humidity.

The actual total load capacity of the AHU that was calculated using actual data from incoming and outgoing air properties was $62.6 \mathrm{~kW}$, which was $29 \%$ lower than the installed capacity. This capacity is almost identical to the simulated result obtained using building simulation software. This finding is hardly surprising considering that the cooling per area value of the installed AHU exceed recommended range stated in ASHRAE Pocket Guide for Air Conditioning, Heating, Ventilation, Refrigeration. The combination of cyclical relative humidity profile, low actual building load and high 
cooling load per area value clearly indicates that the capacity of the installed AHU is oversized. Comparison between the parameters of the original installation, simulated condition, simulated heater, simulated bypass and installed bypass AHUs is shown in the table below:

Table 3: Comparison of AHU Data and Performance

\begin{tabular}{lcccc}
\hline Description & Original & Simulated & $\begin{array}{c}\text { Simulated } \\
\text { Face Bypass }\end{array}$ & $\begin{array}{c}\text { Installed } \\
\text { Face Bypass }\end{array}$ \\
\hline AHU Capacity $(\mathrm{kW})$ & 87.4 & 62.0 & 87.4 & 87.4 \\
Fan Airflow $(\mathrm{L} / \mathrm{s})$ & $4,870.5$ & $2,794.0$ & $4,870.5$ & $4,870.5$ \\
Cooling per area $\left(\mathrm{W} / \mathrm{m}^{2}\right)$ & 218.9 & 155.3 & 218.9 & 218.9 \\
Room Temperature $\left({ }^{\circ} \mathrm{C}\right)$ & 22.1 & 24 & 22 & 22.6 \\
Room Relative Humidity $(\%)$ & 70.5 & 50 & 60.5 & 62.8 \\
\hline
\end{tabular}

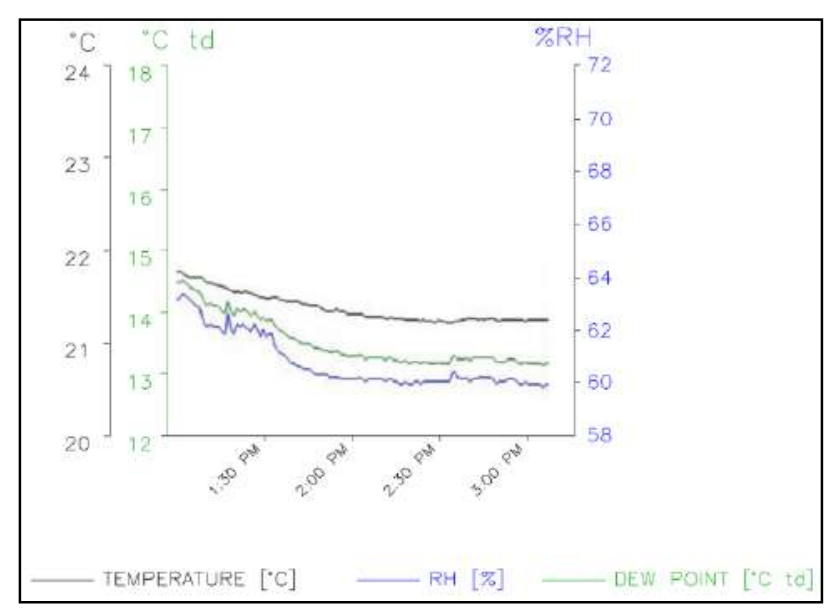

Fig. 5: Room Temperature and Relative Humidity after installation of Face Bypass Damper

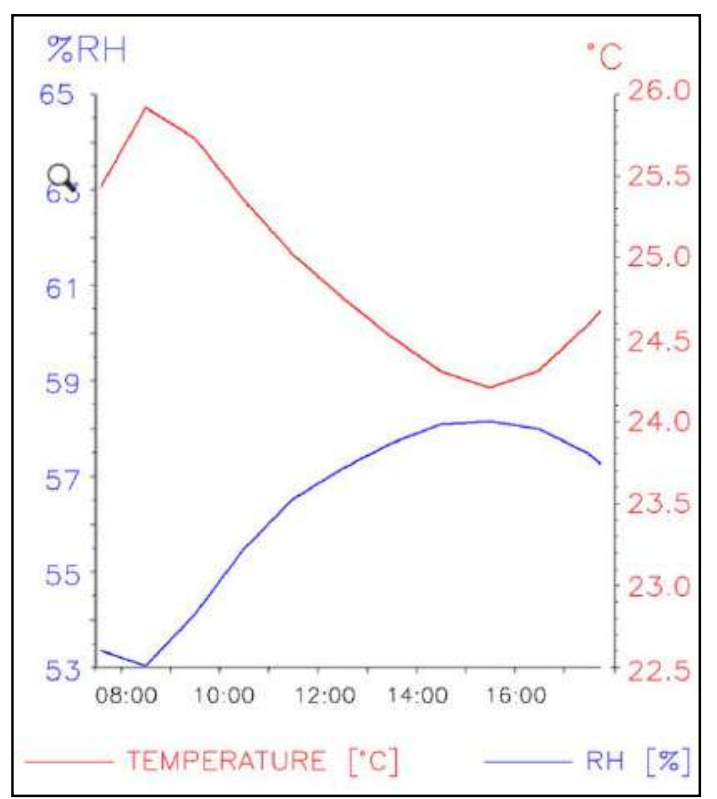

Fig. 6: Simulated Temperature and Relative Humidity Profiles of Face Bypass Damper

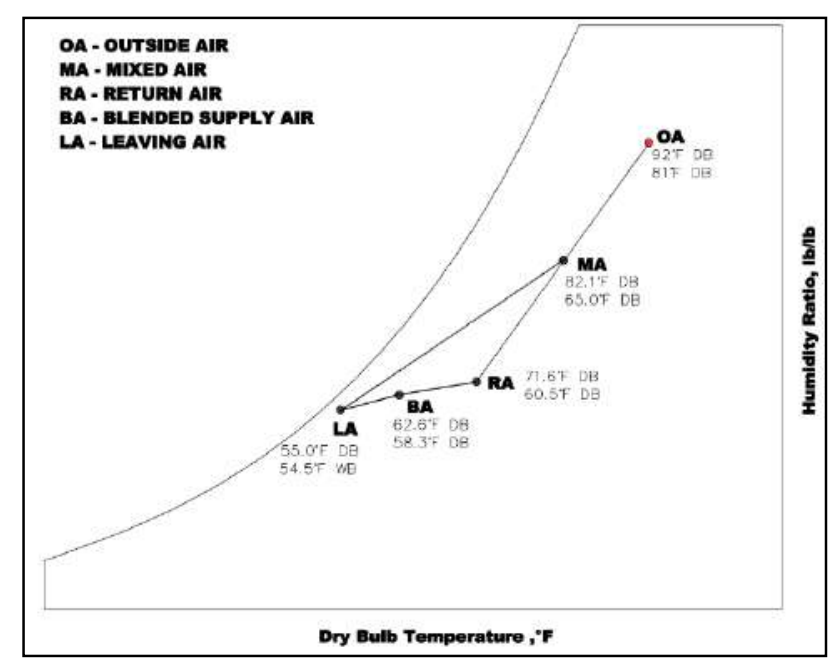

Fig. 7: Performance of Face Bypass Damper AHU

From the AHU data and performance above, it can be seen that the initiative to install face bypass damper to the original AHU effectively reduces relative humidity. The impact on mould is immediate in which it is successful in stopping further growth progression. It is expected that once all existing mould at ceiling and wall are removed properly, the hospital building will be able to operate without any health concern.

Face bypass damper is able to achieve this by allowing incoming fresh air to be dehumidified through cooling coil while the bulk of the relatively dry returning air could be bypassed around the coil to re-enter the conditioned space. By diverting a portion of incoming air, the burden of the cooling coil could be lessened. The result also shows that the impact of the bypass air is comparable to a heater whereby hotter returning air reheats the cooled air stream leaving the coil without significantly affecting the outgoing air's humidity ratio. Since modulating valve is fixed, cooling coil surface temperature is kept sufficiently low to ensure that air passing through it gets sufficiently dehumidified to its desired level. The face bypass damper can then be modulated to suit conditioned space requirement. Should the need to reduce sensible heat arises, the face bypass damper can then be closed to enable all incoming air to flow to be cooled by the cooling coil.

The result also shows that the simulated model using face bypass damper is able to generate almost identical result compared to the actual installation. This shows that usage of simulation software is a reliable tool in predicting performance of air conditioning system in real-life situation. The advantage of using face bypass damper can be further highlighted when it was compared to the traditional method of installing an electric heater. While simulation data supports the assumption that heater installation can effectively reduce relative humidity, it comes with significant energy penalty. At full capacity, the AHU could consume $48 \%$ more energy to reduce air temperature to match required relative humidity while 
simultaneously heat up the heating element in order to raise the air temperature back to comfort level. In contrast, the psychometric chart shows that AHU with face bypass damper installed was able to utilize $44 \%$ of the heating requirement from the bypassed air. The only drawback is that the bypassed air carries some added moisture whereas a heater system will be able to keep the leaving air at the necessary humidity ratio. However, face bypass damper can still reduce energy consumption while achieving the required temperature and relative humidity.

Table 4: Comparison of AHU Data and Performance

\begin{tabular}{lccc}
\hline Description & $\begin{array}{c}\text { Simulated } \\
\text { Original }\end{array}$ & $\begin{array}{c}\text { Simulated } \\
\text { Heater }\end{array}$ & $\begin{array}{c}\text { Simulated } \\
\text { Face Bypass }\end{array}$ \\
\hline AHU Capacity $(\mathrm{kW})$ & 87.4 & 129.0 & 118.5 \\
Fan Airflow $(\mathrm{L} / \mathrm{s})$ & $4,870.5$ & $4,870.5$ & $4,870.5$ \\
Cooling per area $\left(\mathrm{W} / \mathrm{m}^{2}\right)$ & 218.9 & 322.9 & 296.7 \\
Room Temperature $\left({ }^{\circ} \mathrm{C}\right)$ & 23.3 & 24.7 & 22 \\
Room Relative Humidity $(\%)$ & 80.3 & 59.1 & 60.5 \\
\hline
\end{tabular}

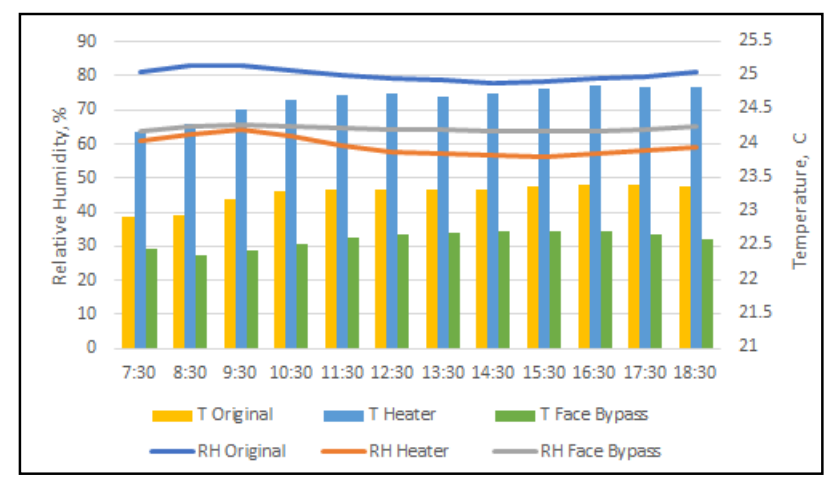

Fig. 8: Temperature and Relative Humidity Profiles of Simulated Original, Simulated Heater and Simulated Face Bypass Damper

\section{Conclusion}

This study has shown that oversized air conditioning system leads to high relative humidity which contributed to hazardous mould growth. The introduction of a face bypass damper, as shown in this study, successfully reduced the overall relative humidity of the conditioned space. The hospital should be mould-free once all the mould spores are cleaned and removed from its environment. However, this method should not be used as a standard measure to tackle mould issue because energy is still wasted to power the higher capacity fan. Moreover, there is also energy wastage on the overall air conditioning system because the modulating valve is kept open to ensure low surface temperature at cooling coil. Thus, it incurs extra demand on the chiller to continuously supply the needed chilled water. While energy incurred by a single AHU might be negligent, it could add up significantly when applied to every AHU in the hospital. As shown by the simulation result, an optimally sized AHU is still the best answer to deliver the desired temperature and relative humidity with minimum energy consumption. Retrofitting face bypass damper on existing AHU should only be used as a corrective measure that is implemented only due to time and cost constrains.

This study also shows the dependability of using building simulation software to determine air conditioning system performance. While other calculation method exists, it is mostly limited to optimize the equipment's capacity with relation to energy consumption. Building simulation software gives the added advantage of analyzing the impact of various air conditioning system's configuration on temperature, relative humidity and many other essential perimeters. This information can be used to solve real life problem including health concern caused by mould growth. Its findings can later be confidently applied to existing installation, thereby significantly reducing time, risk and cost required to experiment.

\section{Nomenclature}

$h$

$c_{p a}$ specific heat of air at constant pressure $\left(\mathrm{J} / \mathrm{kg} \cdot{ }^{\circ} \mathrm{K}\right)$

$t \quad$ air temperature $\left({ }^{\circ} \mathrm{C}\right)$

$x \quad$ humidity ratio (gram/kg)

$c_{p w} \quad$ specific heat of water vapor at constant pressure $\left(\mathrm{J} / \mathrm{kg} \cdot{ }^{\circ} \mathrm{K}\right)$

$h_{\text {we }} \quad$ evaporation heat of water at $0^{\circ} \mathrm{C}(\mathrm{kJ})$

\section{References}

1) Suruhanjaya Tenaga Malaysia, "National energy balance 2018”, Suruhanjaya Tenaga Malaysia, 2018. https://meih.st.gov.my/documents/10620/f2f4c39b4748-4c5d-b90a-fc36ba880264

2) "Annual economic statistics 2018: construction," https://www.dosm.gov.my/v1/index.php?r=column/c themeByCat\&cat=321\&bul_id=dmdCbDFpaW96W kFmWjZZL0xma1hFUT09\&menu_id=OEY5SWtF SVVFVUpmUXEyaHppMVhEdz09 (accessed December 17, 2020)

3) C.K. Tang, N. Chin, and S. Misara, "Building energy efficiency technical guideline for active design”, Building Sector Energy Efficiency Project (BSEEP) Malaysia, 2017.

4) M.T. Kibria, M.A. Islam, B.B. Saha, T. Nakagawa and S. Mizuno, "Assessment of environmental impact for air conditioning systems in Japan using HFC based refrigerants," Evergreen, 6 (3) 246-253 (2019). doi:10.5109/2349301.

5) M.A. Islam, A. Pal, K. Thu, and B.B. Saha, "Study on performance and environmental impact of supermarket refrigeration system in Japan", $\begin{array}{lllll}\text { Evergreen. } & 6 & \text { (2) } 168-176 & \text { (2019). doi: }\end{array}$ $10.5109 / 2321014$. 
6) A.Pal, K. Uddin, K. Thu, and B.B. Saha, "Environmental assessment and characteristics of next generation refrigerants", Evergreen. 5 (2) 58-66 (2018). doi: 10.5109/1936218.

7) M. Isaac, and D.P. van Vuuren, "Modeling global residential sector energy demand for heating and air conditioning in the context of climate change", Energy Policy, 37 (2) 507-21 (2009). doi:10.1016/j.enpol.2008.09.051.

8) B. Shahriari, A. Hassanpoor, A. Navehebrahim, and S. Jafar, "Designing a green human resource management model at university environments: case of universities in tehran,” Evergreen, 7 (3) 336-350 (2020). https://doi.org/10.5109/4068612.

9) T. Sato, "How is a sustainable society established? a case study of cities in japan and germany," Evergreen, 3 (2) 25-35 (2016). doi:10.5109/1800869.

10) B. Shahriari, A. Hassanpoor, A. Navehebrahim, and S. Jafarinia, "A systematic review of green human resource management,” 6 (2) 177-189 (2019). https://doi.org/10.5109/2328408.

11) T.M.I. Mahlia, H.H. Masjuki, and I.A. Choudhury, "Potential electricity savings by implementing energy labels for room air conditioner in Malaysia,” Energy Convers. Manag., 43 2225-2233 (2002). https://doi.org/10.1016/S0196-8904(01)00160-1

12) T.M.I. Mahlia, H.H. Masjuki, R. Saidur, and M.A. Amalina, "Viewpoint mitigation of emissions through energy efficiency standards for room air conditioners in Malaysia,” Energy Policy, 32 17831787 (2004). doi:10.1016/S0301-4215(03)00170-8.

13) D.R. Felts, and P. Bailey, "State of affairs - packaged cooling equipment of California", Proc. 2000 ACEEE Summer Study Energy Effic. Build., 3 137-147 (2000).

14) P.C.H. Yu, and W.K. Chow, "Sizing of airconditioning plant for commercial buildings in Hong Kong”, Appl. Energy, 66 (2) 91-103 (2000). doi:10.1016/S0306-2619(99)00126-9.

15) M. Bacon, "Occupancy analytics: a new basis for low-energy-low-carbon hospital design and operation in the UK”, Archit. Eng. Des. Manag., 10 (1-2) 146163 (2014). doi:10.1080/17452007.2013.837254.

16) J. Proctor, Z. Katsnelson, and B. Wilson, "Bigger is not better: sizing air conditioning properly”, Home Energy Magazine Online, 1995. https://homeenergy.org/show/article/nav/hvac/page/3 3/id/1128.

17) R.K. Vieira, J. Klongerbo, J. Sonne, and J. Cummings, "Florida Residential Air Conditioning Sizing Survey Results”, ASHRAE Trans., 101 (2) (1995).

18) T. Watanabe, "Ignorance as a limitation for the application of scientific methods to environmental protection activities," Evergreen, 2 (1) 41-48 (2015). doi:10.5109/1500426.

19) H. McLain, and D. Goldenberg, "Benefit of replacing residential central air conditioning System United States”, American Council for an Energy-Efficient
Economy, 1984.

20) H.I. Henderson, “An experimental investigation of the effect of wet and dry coil conditions on cyclic performance in the seer procedure”, Int. Refrig. Air Cond. Conf., 20-29 (1990).

21) P. James, J. Cummings, J. Sonne, R. Vieira, and J. Klongerbo, "The effect of residential equipment capacity on energy use, demand, and run-time”, ASHRAE Trans., 29 (4) 522-529 (1997).

22) N. Djunaedy, V.D. Wymelenberg, K. Acker, and H. Thimmanna, "Rightsizing : using simulation tools to solve the problem of oversizing," Proc. Build. Simul. 2011, 14-16 (2011).

23) D.B. Shirey, H. Henderson, and R.A Raustad, "Understanding the dehumidification performance of air-conditioning equipment at partload conditions”, Florida Energy Centre Contract Report, 2006. doi:10.2172/881342

24) C. Booten, C. Christensen, and J. Winkler, "Energy impacts of oversized residential air conditioners simulation study of retrofit sequence impacts", National Renewable Energy Laboratory, 2017. doi:10.2172/1164103

25) M.K. Khattar, M.V. Swami, and N. Ramanan, "Another Aspect of Duty Cycling, Effects on Indoor Humidity" ASHRAE Transaction, 93 1678-1687 (1987).

26) K. Ito, "Micro- and macro-scale measurement of fungal growth under various temperature and humidity conditions ", Evergreen, 1 (1) 32-39 (2014). doi:10.5109/1440974

27) Cawangan Kejuruteraan Mekanikal, "Panduan Teknik Mekanikal: Garis Panduan Rekabentuk Penyaman Udara", Jabatan Kerja Raya, 2009.

28) N.C. Burton, P. Taylor, A. Adhikari, Y. Iossifova, S.A. Grinshpun, A. Adhikari, Y. Iossifova, S.A. Grinshpun, and T. Reponen, "Effect of gaseous chlorine dioxide on indoor microbial contaminants effect of gaseous chlorine dioxide on indoor microbial contaminants," J. Air Waste Manage. Assoc., 58 647-656 (2008). doi:10.3155/1047-3289.58.5.647.

29) A.A.H. Khan, and S.M. Karuppayil, "Fungal pollution of indoor environments and its management," Saudi J. Biol. Sci., 19 (4) 405-426 (2012). doi:10.1016/j.sjbs.2012.06.002.

30) Environmental Protection Agency, "Moisture Control Guidance for Building Design, Construction and Maintenance”, United States Environmental Protection Agency, 2013.

31) D. Dybdahl, J. Wade, R. Dwyer, " Under coverage: with new insurance company exclusions on mold and terrorism insurance, owners and managers need to do some careful planning to find appropriate coverage", J. Prop. Manag., 68(3) 36+ (2003)

32) Green Building Index, "GBI Assessment Criteria for Non-Residential New Construction", Green Building Index Sdn. Bhd., 2009. 